\title{
LOGISTICS COSTS IN SOUTH AFRICA - THE CASE FOR MACROECONOMIC MEASUREMENT JAN HAVENGA*
}

\section{Abstract}

In South Africa, logistics optimisation is largely managed from a microeconomic perspective. This paper makes the case for macroeconomic logistics measurement, presents the results of the country's national logistics cost model and proposes the first key macroeconomic logistics indicators for South Africa.

The research shows that South Africa's logistics costs are higher than the global average. The majority of these costs are attributable to road transport, of which the biggest cost driver is fuel, which in turn is determined by volatile oil prices. This poses a significant exogenous risk to logistics cost management in South Africa. The risk can be mitigated through a structural adjustment in long-distance freight transport (from road dominated to rail dominated). The paper concludes by proposing two key macroeconomic logistics indicators to facilitate this process.

JEL Classification: C82, L92, R41, R48

Keywords: State of logistics, logistics cost drivers, macroeconomic logistics indicators, intermodal freight, South Africa

\section{INTRODUCTION}

A cursory perusal of the first and latest policy frameworks of democratic South Africa reveals that both frameworks identified the freight transport network as one of the key challenges to national economic competitiveness, sustainable development initiatives, and broad-based upliftment.

In 1994, one of the six basic principles driving the first democratic policy framework, the Reconstruction and Development Programme, was "an infrastructural programme that will provide access to modern and effective services such as . . . transport" in order to create "a sustainable and environmentally friendly growth and development path" (The Presidency, 1994:8).

Notwithstanding numerous public and private sector efforts in the intervening years, in 2007 the latest policy framework, the Accelerated and Shared Growth Initiative for South Africa, again identified the high cost, inefficiency, and insufficient capacity of the national logistics system as one of the six binding constraints that prevents South Africa from achieving sustainable economic growth (The Presidency, 2007). In his 2010 budget speech, Finance Minister Pravin Gordhan also included logistics infrastructure as one of the key pillars to expand the capacity of the economy to grow sustainably and absorb the excess supply of labour (Gordhan, 2010).

* Director, Centre for Supply Chain Management, Department of Logistics, University of Stellenbosch.E-mail: janh@sun.ac.za 
The contribution of efficient freight logistics infrastructure to sustainable economic growth is echoed by Arvis et al. (2008:54), Rodrigues et al. (2005:14), and Limão and Venables (2001:470).

According to United Nations (2002) research, effective cost reduction in the national logistics system can, however, only be accomplished by measuring and tracking logistics cost components to inform appropriate government policy.

Yet out of the 76 development indicators reported annually by the presidency (The Presidency, 2009), not one refers to freight logistics or the key role it plays in the country's development and economic competitiveness. The same holds for the regular macroeconomic indicators tracked by the South African Reserve Bank and Statistics South Africa also.

The key issue here is that the backbone of all high-performing systems is management information (Fredendall and Hill, 2001:213). This holds true irrespective of whether the performance of businesses, industries or entire economies is at stake.

The continuous national strategic mention of the importance of logistics to South Africa's global competitiveness amounts to mere lip service because the current debate is not based on actual measurements that can guide future policy. A case in point is the R80 billion planned spending by Transnet over the next 5 years on logistics infrastructure (Transnet, 2009) and the R106 billion allocated to national and provincial roads over the next 3 years (National Treasury, 2009a, 2009b), where no evidence of long-term collaborative planning is evident despite the extreme long-term nature of such interdependent infrastructure.

The impact of both sufficient and insufficient measurement was illustrated in South Africa recently. Sound monetary and fiscal decisions, enabled by robust macroeconomic indicators, allowed the country to weather the global financial crisis admirably. On the contrary, a lack of management information on the impact of high economic growth and equal access on South Africa's energy demand resulted in a severe backlog in electricitygenerating infrastructure. Similar challenges face the freight logistics discipline because of the lack of management information.

This situation is not unique to South Africa, or even the developing world; it is a global phenomenon. Anderson and van Wincoop (2004:692) found that direct measures of local distribution costs and international trade costs are "remarkably sparse and inaccurate." According to Hesse and Rodrigue (2004:171), research on freight transport and related logistics is "widely underrepresented" and "neglected."

The development of South Africa's freight logistics model therefore provides an important contribution to the quantification of logistics costs in national economies and enables the first quantification of macroeconomic logistics indicators for South Africa. The model was developed to measure and track national freight logistics costs on an annual basis. Freight logistics for the purpose of the model's formulation is defined as:

\footnotetext{
...that part of the supply chain process that deals with the transportation, warehousing, inventory administration and management of commodities between the origin (that is, where they are produced, mined or cultivated) and the destination (that is, the point of delivery to the consumer, either as input to further production processes or for consumption). By definition, this excludes the cost of passenger transport transport, storage, packaging and handling of mail and luggage - and storage and transport tasks that occur during the production, mining or cultivation process (Botes et al., 2006:4).
} 
In view of the fact that the final infrastructure cost responsibility within the various modes of freight transport rests on the users of freight transport services, the recovery of these costs takes place by incorporating it in the freight transport tariffs that users pay. As this applies to all modes of freight transport in South Africa, the logistics cost model by default includes infrastructure cost recovery for each year.

This article endeavours to make the case for the macroeconomic relevance of freight logistics cost measurement, shares the results of the latest model and proposes key macroeconomic logistics indicators.

The next section discusses the macroeconomic relevance of measuring logistics costs. Section 3 provides an overview of the methodology applied in developing South Africa's logistics model. Section 4 discusses the outputs of the model and proposes key indicators. Section 5 summarises the findings and recommends a way forward.

\section{THE MACROECONOMIC RELEVANCE OF MEASURING LOGISTICS COSTS}

The role of logistics in the integration of macroeconomic production factors falls squarely within the ambit of economics. Economic science has been described as "an empirical social science studying those activities that involve the production and exchange of goods" (Mohr and Fourie, 1996:17) or a science that "analyses the movements in the total economy, and commerce amongst economies" (Samuelson and Nordhaus, 1989:4). Logistics is, therefore, an integral component of economics, enabling, inter alia, regional specialisation (and there by economic growth) through the efficient and effective distribution of resources and outputs (Pienaar, 2009:1).

In South Africa, this was evident during most of the 20th century through the employment of the transport industry to drive the government's specific economic objectives. ${ }^{1}$ Prior to the 1990s, the heavy regulation of the South African freight transport industry created complacency regarding the need for freight transport information. The perception existed that through the state-owned monopoly, road permit information and surveys conducted by the then Central Statistical Service, sufficient information regarding the structure of the freight transport industry could be accessed when required for policy formulation or investment decisions. ${ }^{2}$

In the early 1990s, however, the convergence of three defining events in South Africa's history, together with their implications, significantly changed both the structure of the South African economy and the resulting demand for logistics services, namely:

\footnotetext{
${ }^{1}$ Before the 1970s, the policy of import substitution industrialisation (reliant on the development of primary industries) was supported through an artificial economic advantage created for the national rail transport operator, largely because of stringent road transport legislation (Mitchell, 2006). Even during the gradual trade liberalisation of the 1970s and 1980s to facilitate export diversification, the road transport industry was closely regulated through the permit system (Hobbs and Havenga, 2009).

${ }^{2}$ Before deregulation, the railways had a large market share, and detailed information on freight flows and costs were recorded by the institution and were available for planning. As its market share declined, information became scarcer.
} 
- Continued delays in rail infrastructure investment, ${ }^{3}$ the eventual deregulation of the freight transport industry and the creation of Transnet in 1990 resulted in a proliferation of road transport service providers, significantly reducing rail density and increasing road infrastructure requirements (Havenga, 2007).

- The transition to a democratic government caused a step-change in the domestic consumer base, with a concomitant significant rise in demand for consumer products (Hanival and Maia, 2008) and resulting logistics services.

- Trade liberalisation in the 1990s, which not only increased imports, but by reducing both input costs and the relative profitability of domestic sales, also boosted exports (Edwards and Lawrence, 2006).

While many obvious positive outcomes resulted from these events, the country's freight logistics infrastructure came under increasing strain. This culminated in the Barloworld Supply Chain Foresight Study reporting that "many South African businesses have cited the imbalances in the country's supply chain and logistics infrastructure as the cause of their increasing lack of competitiveness" (Logistics News, 2006:13). In a follow-up study, the same target research audience (chief executives and senior supply chain managers) reported concern for "pressures placed on South Africa's supply chains by increasing local demand, and by the increases in supply chain complexity brought about by rapid globalisation and a new diversity in the customer base of many companies" (Logistics News, 2007:2).

A number of international studies highlight the important relationship between logistics and national competitiveness:

- According to the United Nations (2002:22), the comparative efficiency of a country's logistics chain is of vital importance in enhancing the competitiveness of its industry and commerce.

- Lakshmanan and Anderson (2002:3) show that improved productivity in the freight transport sector enhances the productivity of the overall economy.

- The World Trade Organisation (2004) reports that "the effective rate of protection provided by transport costs is, in many cases, higher than that provided by tariffs."

- In a technical study to determine the quantitative role of transport in international business cycles, Ravn and Mazzenga (2004:657) found significant welfare effects resulting from changes in transport costs. The authors estimate that a reduction in transport costs from $20 \%$ to $15 \%$ of gross domestic product (GDP) is equivalent to a permanent increase in domestic consumption of just above $1.5 \%$.

Yet even at a company level, strategic attention to logistics as a source of competitive advantage is a relatively new phenomenon. During the 1980s, competitive advantage meant delivering flawless product quality, while in the 1990s, the focus shifted to providing superior customer service. When these avenues were exhausted (mainly because of emulation by competitors), companies became increasingly aware that a well-run logistics system could provide them with a sustainable competitive advantage (Gourdin, 2001:8). It is therefore not surprising that the macroeconomic shift towards strategic logistics management is still in its infancy.

3 Although widely acknowledged, there is no independent study on the investment backlog in South Africa's rail technology (Department of Transport, 2010). 
In the literature the element of macroeconomics that does receive some attention relates to investment in logistics infrastructure. In this case, investment in infrastructure is viewed as a direct economic injection and a strengthening of the "capital" production factor. Lakshmanan and Anderson (2002:6) describe this better-known field of study in terms of its accepted positive correlation and the regulatory impacts that are therefore required, but they are careful to note the deficiencies in the body of knowledge around the networks created by different modes and the effect of this on production factors. In so doing, they indicate the way towards a more robust understanding of the effect of different modes on network design to benefit an economy as a whole.

Similarly, in South Africa, the infrastructure component is understood in general, but without an understanding of the concomitant network and modal view. Fourie (2008) highlights that the policy and research emphasis in South Africa is still on infrastructural quantity as opposed to quality. He also asks for the reconsideration of infrastructure from an economic perspective. He observes positive contribution rates to economic growth but also sites difficulties in infrastructure econometrics, further confounded in South Africa because of a lack of data and "a perplexed past" (Fourie, 2006:553-554).

In a detailed historical analysis spanning 106 years, Fedderke et al. (2006) demonstrate that the impact of infrastructure investment on economic growth is both strong and statistically significant. Perkins et al. (2005:221) highlight that infrastructure development took place in phases and conclude that "since the economy's infrastructure requirements tend to change over time, and since infrastructure projects tend to take place on a large scale and are therefore expensive, this pattern of infrastructure phasing is unsurprising and is likely to continue." While both papers provide significant a posteriori evidence towards substantiating the importance of infrastructure investment, the research falls short of providing measures of the performance of the various infrastructure categories and in providing a priori guidelines for the significant transport infrastructure investments mentioned previously. The research presented in this paper address both these areas.

Lakshmanan and Anderson (2002:17) emphasise the need for performance-based research to clearly demonstrate the link between logistics infrastructure investment and economic growth. This would enable an understanding of the "effects of logistical transformation, productivity-enhancing location shifts, and value-adding effects" and "ex post assessment of major infrastructure projects and programs." Their appeal is for indicators to inform the development of national logistics strategies and track performance of the macro-logistics system against national strategies.

Demkes and Tavasszy (2000:4) provide four objectives of such measurement performance indicators for the macro performance of logistics infrastructure, namely:

- to establish a holistic view of the system;

- to give feedback in order to initiate a new and better way to conduct and handle the measurement system;

- to clarify the aim and goal for all participants in the system; and

- to indicate important overall policy actions.

Bogetić and Fedderke (2006) benchmarked South Africa's transport performance on basic road and rail indicators against upper middle-income countries based on a new World Bank database. The authors conclude that South Africa's performance is worse than the benchmark upper middle-income countries but recommend a deeper analysis of 
the transport sector to develop a more "nuanced picture" between the different modes.

Pienaar (2005) proposed a procedure through which the increase in regional income that emanates from economically justified road infrastructure provision can be estimated by applying multiplier and accelerator analyses. His emphasis on economically justified roads indicates a focus on quality as opposed to quantity. Subsequent to further development of his 2005 regional income model, he in 2008 applied it in a real-life situation in the north eastern part of Namibia (Pienaar, 2008). This work demonstrated how regional income can increase through improved business logistics services and greater accessibility. Pienaar (2010) later extended his freight transport modal work to also incorporate the effect that efficient commercial pipeline operations can have on logistics effectiveness in a country.

The findings from the logistics cost model and resulting key indicators (discussed in Section 4) not only address the aforementioned objectives of Demkes and Tavasszy (2000) but also enable a more nuanced modal view as proposed by Bogetić and Fedderke (2006) and Pienaar $(2005,2008,2010)$. The model provides:

- the only available national view of the state of logistics in South Africa;

- a bottom-up approach (described in the next section) that enables a detailed modal view as well as the refinement of the measurement on a detailed scale;

- an understanding of the national state of affairs which (i) focuses the activities of all participants on the impact of individual activities on the broader logistics environment, and (ii) enables more strategic and collaborative decision making at an industry and government level; and

-a holistic view of the state of logistics that enables government to engage meaningfully with stakeholders to address the country's logistics challenges.

\section{METHODOLOGY}

As per the definition of logistics provided in Section 1, logistics costs can be broken down into three direct elements, namely transport, storage and port handling costs, and management and administration costs, and one indirect element, namely inventory carrying costs (time-based working capital financing the cost of inventory in the logistics chain).

The results from the first model (Botes et al., 2006) and subsequent discussions with government and industry stakeholders pointed to the need for further refinement to the following areas of the model:

- Firstly, transport was identified as the largest component of South Africa's logistics cost in the first model, and extensive refinements were therefore made to this cost component in subsequent models (discussed in Section 3.1 below).

- Secondly, the initial model applied a static warehousing cost estimate based on an estimation of the average inventory level for 1 year - this required expansion to include a more robust year-on-year inventory cost comparison.

- Lastly, whereas all the other elements of the model estimated full costs, inventory carrying costs (or the opportunity cost of capital) was based on value-added costs, which underestimated inventory carrying costs and did not enable industry-level benchmarking. This was adapted to enable calculation of the opportunity costs of capital employed in each stage of the value chain. 
The logistics cost model employs a bottom-up approach for the computation of logistics costs by aggregating detailed commodity-specific data - relating the tons produced and imported (that is total supply) of a specific commodity to the costs of performing logistical functions with respect to that commodity. As mentioned, the logistics cost elements measured are transport, storage and port handling costs, management and administration costs, and inventory carrying costs as illustrated in equation (1) below.

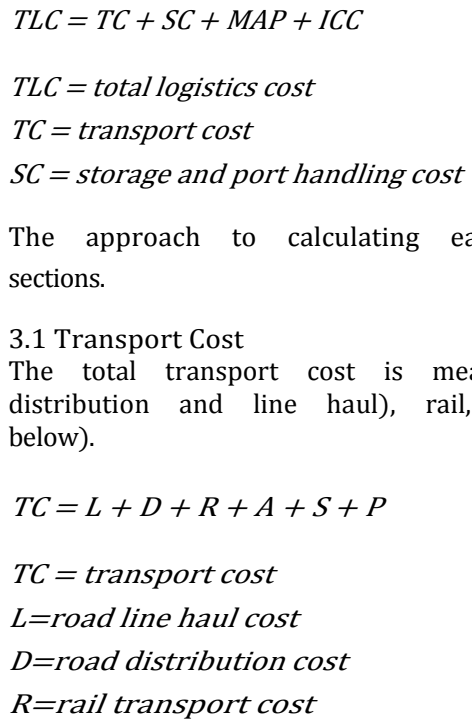

The methodology for each component of the transport cost is described below.

(i) Road Transport Cost In-house road transport costs and/or volumes are not officially measured by any government agency in South Africa and are therefore not available on a national level. Only road transport for reward is estimated by Statistics South Africa. ${ }^{4}$

In order to determine total road transport costs, road freight flows were developed. This addresses an important concern raised by Hesse and Rodrigue (2004), who advocate the inclusion of a spatial dimension in future freight transport research as it provides "a more comprehensive insight into the nature of distribution and its geographical dimensions" and enables value chain integration.

Road flows in South Africa were determined through the modelling of total freight flows in the economy on a 62-commodity-groupings and 356-magisterial-districts level, subtracting rail, coastal, pipeline, and conveyer belt flows. ${ }^{5}$ The remaining flows are road flows of commodities between specific origin-destination pairs (up to delivery at the final

\footnotetext{
${ }^{4}$ In-house road transport is the road transport services provided by the freight owner, whereas road transport for reward refers to the outsourcing of the function. The road transport-for-reward industry, and not the cost of transport, is surveyed by Statistics South Africa.

5 The non-road modes are known, readily available through desktop research, or negligible. Actual rail and pipeline flows were obtained from Transnet. Coastal shipping and air transport account for less than $1 \%$ of total tons transported and are easily determined; conveyor belt flows (although large) are used by only two entities (Eskom and Sasol) and are therefore easily researched. This is a major extension of the previous logistics cost model that estimated a single average transport
} 
warehouse), which can be translated into the costs depicted in equation (3) below.

$\mathrm{L}=\sum_{\mathrm{i}=1}^{\mathrm{n}} \sum_{\mathrm{j}=1}^{\mathrm{p}} \sum_{\mathrm{k}=1}^{\mathrm{s}} \mathrm{xy}_{\mathrm{ijk}}\left[(\mathrm{d}+\mathrm{c}+\mathrm{l}+\mathrm{q}+\mathrm{e}+\mathrm{f}+\mathrm{m}+\mathrm{z})_{\mathrm{ijk}}+\mathrm{t}_{\mathrm{k}}\right]$

(3)

$L=$ road line haul cost
$i=$ commodity grouping
$j=$ typology
$k=$ route
$n=$ number of commodity groups
$p=$ number of typologies
$s=$ number of routes
$x=$ tons transported
$y=$ distance in kilometres
$d=$ depreciation rate per tonkm

\author{
$q=$ insurance per tonkm \\ $e=$ driver fees per tonkm \\ $f=$ fuel cost per tonkm \\ $m=$ maintenance and repair costs per tonkm \\ $z=$ tyre wear cost per tonkm \\ $t=$ toll fees per tonkm \\ $c=$ cost of capital per tonkm \\ $\mathrm{I}=$ licence fee per tonkm
}

The equation involves the summation of all the different cost elements of road transport within a typology ${ }^{6}$ on a specific route (overhead costs are left out of the equation because it is calculated as a separate cost element in the model).

These different cost elements of road transport in the model are determined by a vehicle type; the vehicle type, in turn, is determined by the commodity type, typology and route of travel. The commodity's "preferred" vehicle type will change with changes in each of these variables. Once the vehicle type and volume are known, the cost elements can be assigned according to equation (3) above.

The core drivers of transport costs, i.e. weight in tons (x) and distance travelled (y), describe the base of the formula. In the previous model, a standard and single average transport distance (ATD) assumption per commodity was made, and this ATD was then multiplied by the tons of the commodity produced in the economy in order to determine the line haul ton-kilometres for that commodity. In the revised approach, and with the assistance of knowledge gained from the freight demand model (Havenga, 2007), it was possible to deconstruct each commodity's flows into 39 distinct typology (freight flow market segment) subgroups. Based on where the commodity flowed and the distance of that flow, each flow could also be attributed to one of 34 possible vehicle combinations. The previous model used one average cent per ton-kilometre cost, but in this model, a separate cent per ton-kilometre for each of the 34 vehicle types was applied. Moreover, other costs that are determined by the typology, such as fuel costs and toll fees, could also be defined and calculated separately. By using 34 vehicle combinations over 39 typology subgroups, the single cent per ton-kilometre measurement of the previous model could be extended to $34 \quad ¥ 39$ (i.e. 1,326) possible cost measurements.

The model also required an extension to include secondary road traffic (i.e. local distribution from the final warehouse to the retailer), and this is reflected in equation (4) below.

distance per commodity (refer to Havenga, 2007 for a detailed exposition of the freight demand model).

${ }^{6}$ Three main typology groups are identified: freight flows over long-distance corridors, those in rural areas and those in metropolitan areas. 
$\mathrm{D}=2\left[\sum_{\mathrm{i}=1}^{\mathrm{n}} \sum_{\mathrm{j}=1}^{\mathrm{p}} \sum_{\mathrm{k}=1}^{\mathrm{s}} \mathrm{x}_{\mathrm{ijk}}\left[(\mathrm{d}+\mathrm{c}+\mathrm{l}+\mathrm{q}+\mathrm{e}+\mathrm{f}+\mathrm{m}+\mathrm{z})_{\mathrm{ijk}}+\mathrm{t}_{\mathrm{k}}\right] \mathrm{w}\right]$

$D=$ road distribution cost

$w=$ average distribution distance

(ii) Rail Transport Cost Actual rail transport costs are received from the national rail transport operator (Transnet Freight Rail) per commodity per origin-destination station. Rail transport costs, therefore, do not have to be modelled. The rail origin-destination pairs, however, had to be allocated manually to the same corridor, metropolitan, and rural typologies, as the road flows, in order to subtract them from total flows in the freight demand model and also to enable granular market share comparisons. From the manual allocation, a conversion table was developed to enable the use of the historical rail freight database. A conversion table was also developed to classify the 321 rail commodities into the 62 commodity groups. The railways has subsequently added the 62 commodity group classification system to its core database (in the previous model, actual rail flow data per commodity was not used; instead, it was modelled from total economic production and total rail income).

(iii) Air Transport Cost Air freight volume accounts for a very small portion of total freight transport in South Africa. It is still included in order to allow calculation of the total cost of logistics and enable analysis of trends in this transport mode.

Air freight volume data are available only as a total figure (not with a commodity split or any origin/destination pairs), and therefore, the equation is less complex, as reflected in equation (5) below.

$A=x \times r$

$A=$ air transport cost

$r=$ the average tariff per ton to transport goods by air

Efforts are currently underway to improve the quality and granularity of air transport data in order to improve this aspect of the model.

(iv) Coastal Shipping Cost Coastal shipping refers to the transport of commodities between South African ports. This cost element consists of three components: the shipping of petroleum in oil tankers, the shipping of break-bulk and the shipping of containers on container ships. Petroleum is by far the largest volume contributor, contributing approximately $90 \%$ of the total. The transport costs for each of these components were researched and aggregated as per equation (6) below.

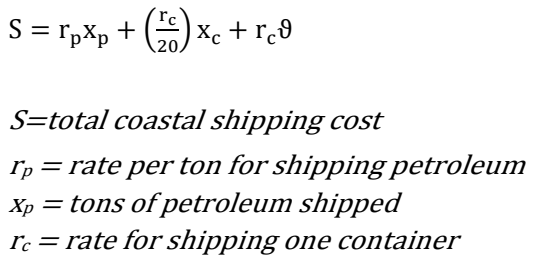




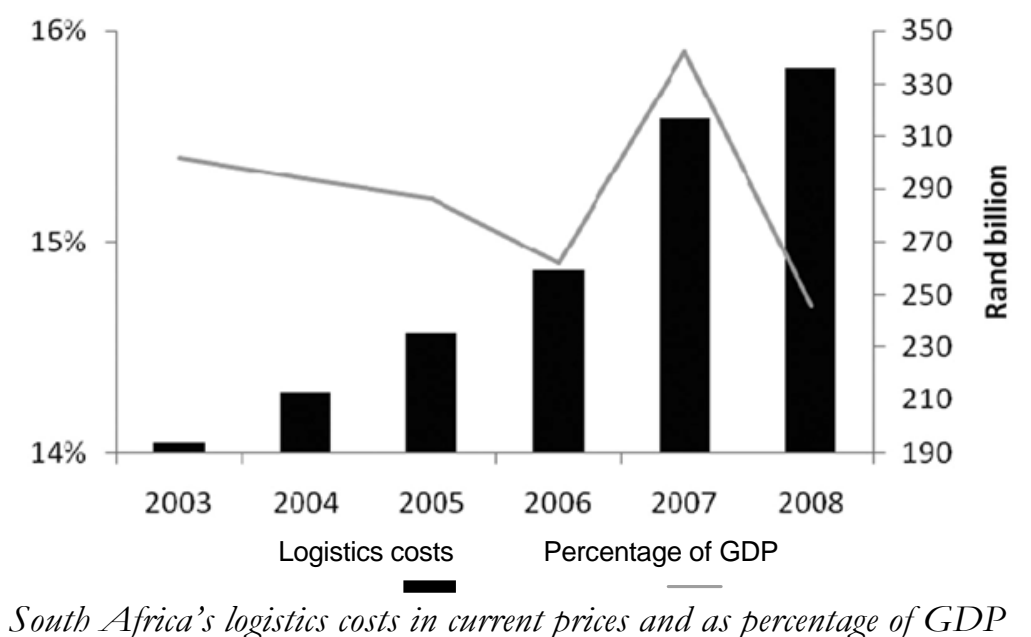

Figure 1. South Africa's logistics costs in current prices and as percentage of GDP

\subsection{Inventory Carrying Cost}

The inventory carrying cost is calculated by researching the rand value of inventory levels for different industries in the economy and then multiplying that value by the weighted average repo rate for the year (equation (10)).

$$
I C C=\sum_{u=1}^{o} r_{i} e_{r}
$$

\section{$I C C=$ inventory carrying cost \\ $u=$ industry type \\ $o=$ number of industries}

$$
\begin{aligned}
& r_{i}=\text { cost of inventory } \\
& e_{r}=\text { weighted average repo rate for the year }
\end{aligned}
$$

\subsection{Management, Administration and Profit}

The methodology proposed by Botes et al. (2006) is still in effect here. The cost of management and administration is calculated as a percentage of the unit cost of transport and warehousing. This percentage, which varies according to storage type and transport mode, is derived from information obtained from operators and practitioners. Efforts are currently underway to improve this calculation for future model updates.

\section{DISCUSSION OF MODEL RESULTS}

\subsection{South Africa's Logistics Cost in the Global Context}

The results from the 2008 logistics cost model, as illustrated in Fig. 1, indicate that South Africa's total cost of logistics for 2008 was R339 billion, equal to $14.7 \%$ of GDP.7 Logistics costs, relative to GDP, are at their lowest level since the inception of the survey

\footnotetext{
${ }^{7}$ Care should be taken when comparing logistics costs and GDP, as discussed in Rossouw (2006) and Macrosys (2005). Logistics do not contribute x percent to GDP because GDP includes only the value added from sector to sector and is not a summation of the turnover of all business activities in the economy. Therefore, one could make the statement that logistics costs are equal to a percentage of GDP, but this would simply be a statement of their relative size, not a statement of how much one is dependent on the other. Comparing relative size, however, does enable benchmarking of the economy as a whole to other economies in the world.
} 


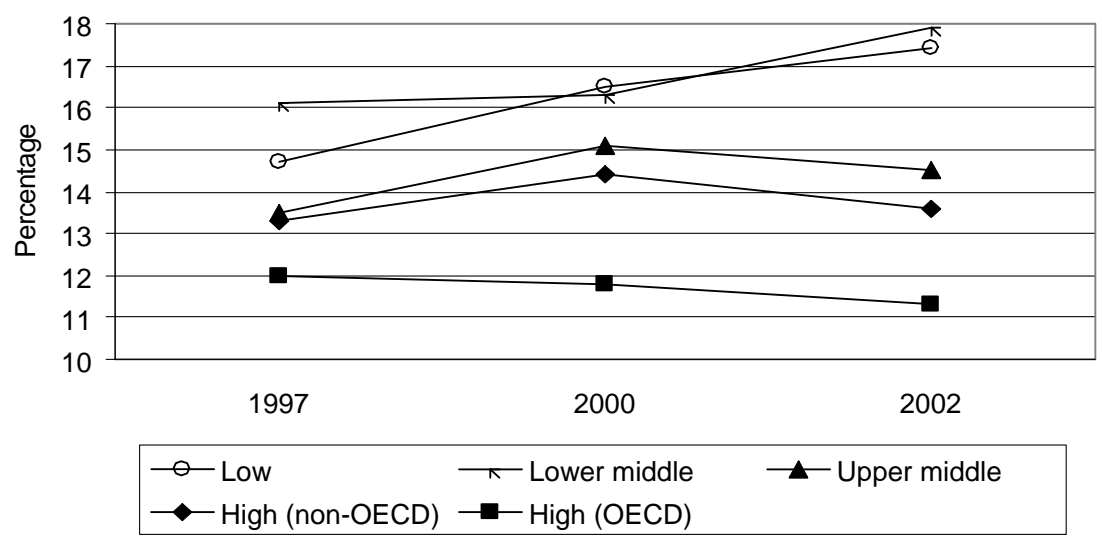

Figure 2. Logistics costs as percentage of GDP-based income groups per country (Rodrigues et al., 2005)

(the recent fluctuations in logistics costs as a percentage of GDP, discussed in Sections 4.2 and 4.3 , are due to fluctuations in the key exogenous variable, and not to an intrinsic improvement in logistics efficiency.)

Indications are that South Africa's logistics costs, as a percentage of GDP, are high in global terms. ${ }^{8}$ Bowersox and Closs (1996:128) calculated an average for industrialised nations of $11.7 \%$. According to the United Nations (2002:22), Japan's logistics costs are about $10 \%$ of GDP, while in the USA, the figure was 10.1\% in 2007 (Wilson, 2008:1). ${ }^{9}$

For some less-developed economies, these costs exceed 30\%. Moreover, the differences between countries appear to be widening (Bowersox and Closs, 1996:128).

In an attempt to address these challenges, Rodrigues et al. (2005) developed an artificial neural network approach to compare global logistics costs by country. They used 24 countries (representing $75 \%$ of global GDP in 2002) in their calculation. The findings of the study are disconcerting for developing nations, as they report that logistics costs of countries used in their study rose from $13.4 \%$ in 1997 to $13.8 \%$ in 2002. During the period of their research, logistics costs decreased for upper- and high-income nations yet increased for nations with lower incomes and, in relative terms, are also higher for nations with lower incomes, as illustrated in Fig. 2. Anderson and Van Wincoop (2004:747) confirm that on average, trade costs in developing countries significantly exceed that of developed countries, in some cases by a factor of two or more.

Rodrigues et al. (2005:13) hypothesise that this could be caused by increased operational pressures in the first world, as well as higher density. Both these observations are of importance for the situation in South Africa today. The development potential of

8 Global comparisons are difficult as many countries do not measure national logistics costs, methodologies differ and some measurements are sporadic. Yet as aptly stated by Rodrigues et al. (2005), despite the limitations of the research, the importance of sizing the logistics market to the development of national policy serves to justify a continuous effort to develop and refine the methodology, which is partly informed by the continuous application of the research.

9 The USA 2007 figure was very close to the same as a decade earlier, with $10.2 \%$ measured in 1996 (Wilson, 2008:25). The USA logistics cost, expressed as a percentage of GDP, improved to $8.6 \%$ in 2003 but has deteriorated in recent years to $10.1 \%$ in 2007 (Wilson, 2008:1). 
2004

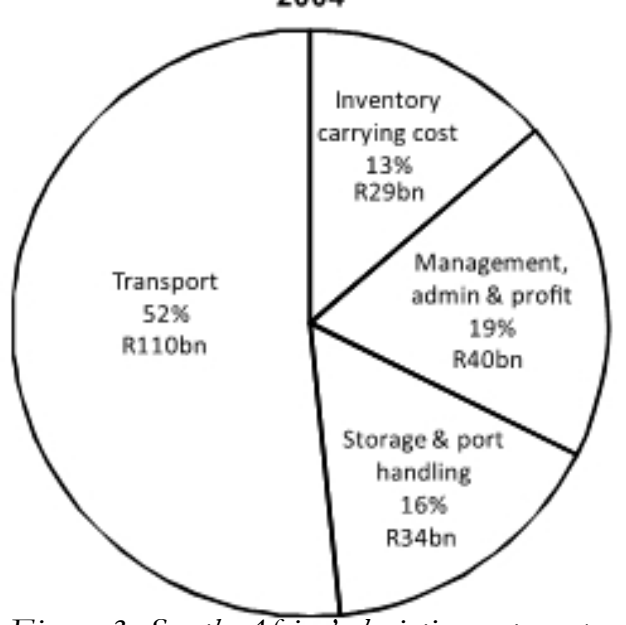

2008

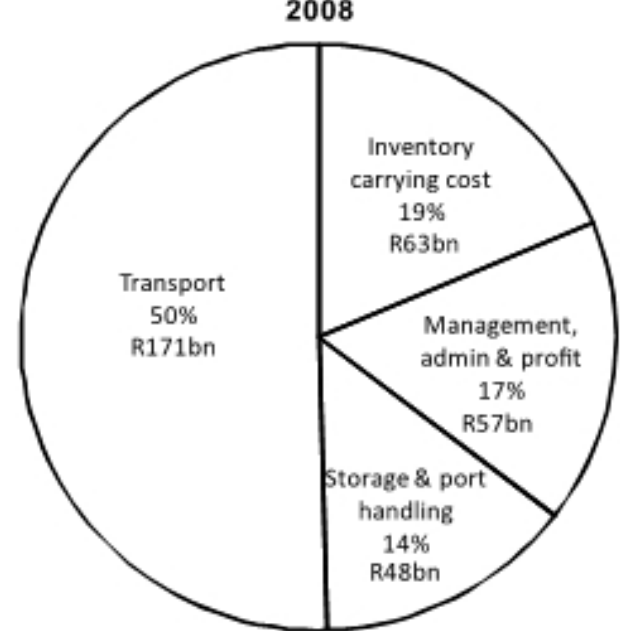

Figure 3. South Africa's logistics cost components in 2004 vs. 2008

the second economy has not yet been achieved, and the full potential cost savings on dense first-economy corridors have not yet been exploited.

The above analysis points to the first macroeconomic logistics indicator proposed for South Africa - the cost of logistics as a percentage of GDP. It enables South Africa to track systemic logistics performance and the overall impact of policies and interventions. This is also the one indicator that is receiving global research attention, thereby enabling comparison with trading partners and competing countries. As a case in point, the US National Research Council (2002) identified logistics costs as a fraction of GDP as one of seven key transportation indicators of economic growth, with its policy relevance defined as "efficiency of overall distribution."

The fluctuations in logistics costs as a percentage of GDP depicted in Fig. 1, however, also emphasise the importance of a more detailed analysis of the components of logistics costs (discussed in the next section).

\subsection{South Africa's Logistics Cost Components}

As depicted in Fig. 3, the composition of logistics costs has remained almost unchanged since model inception, yet Fig. 4 highlights that individual components have shown alarming growth trends. Of specific concern is that transport costs - still by far the biggest cost component - have grown by more than $50 \%$, and inventory carrying costs have doubled between 2003 and 2008. The 2006 step-change in both components also suggests that these two components were responsible for the recent fluctuations in logistics costs as a percentage of GDP (Fig. 1).

From a macroeconomic point of view, four key factors highlight the importance of closer scrutiny of transport costs, specifically ${ }^{10}$ :

- the size of transport's contribution to total logistics costs (Fig. 3);

- recent fluctuations in transport costs (Fig. 4);

- significant freight transport infrastructure investments mentioned earlier; and

The recent growth in inventory carrying costs is discussed in more detail in the Appendix. 


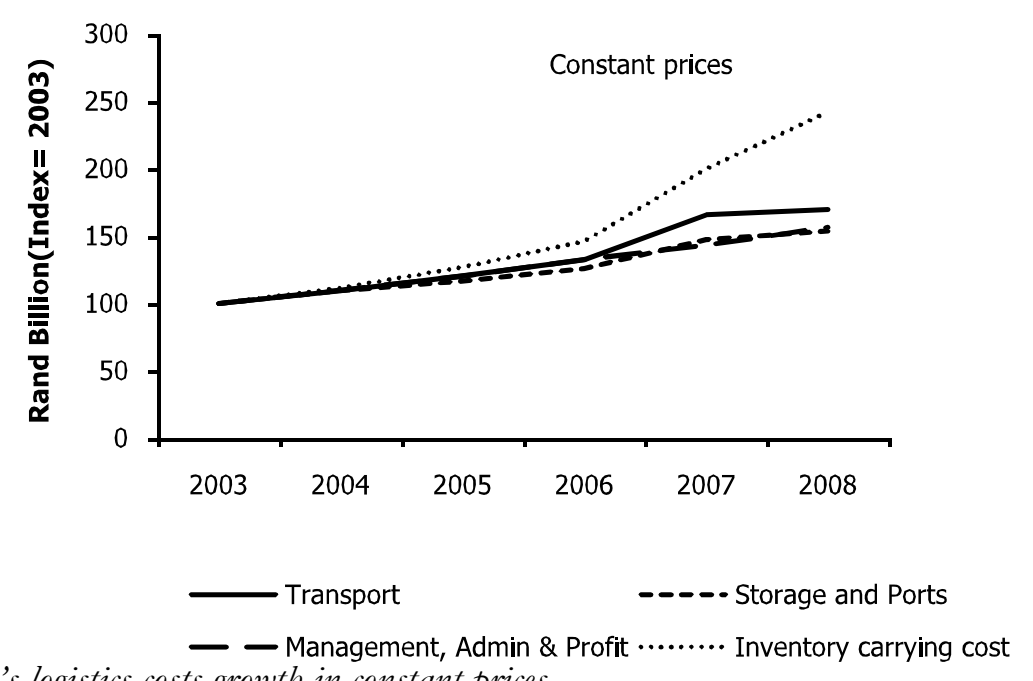

Figure 4. South Africa's logistics costs growth in constant prices

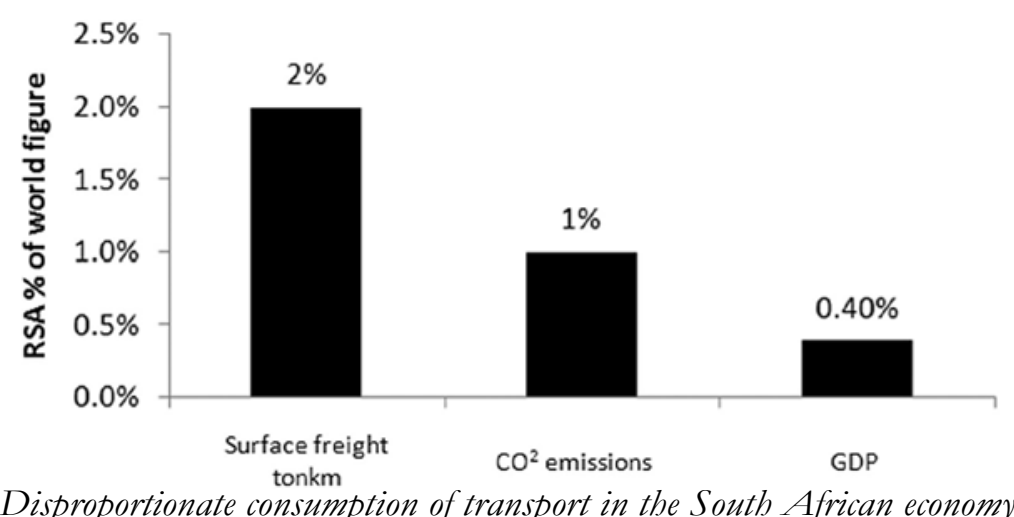

- the fact that South Africa's percentage contribution of transport costs to total logistics costs (53\%) is significantly higher than the world average of 39\% (Rodrigues et al., 2009).

The structure of South Africa's freight transport market is discussed in more detail in the next section.

4.3 Freight Transport Market Structure and Resulting Sensitivity to Exogenous Factors

The demand for transport is a derived demand, which means that as an opportunity cost, unnecessary transport should be eliminated, and transport should be as efficient and effective as possible. As depicted in Fig. 5, South Africa requires a disproportionate amount of this input commodity when compared with GDP. South Africa produces less than half a per cent of the world GDP but requires $2 \%$ of the world's surface freight ton-kilometre, resulting in a contribution of $1 \%$ to the world's $\mathrm{CO}_{2}$ emissions.

The situation depicted in Fig. 5 arises partly from the country's economic development history, with mining production and population development taking place far away from coastal areas, in a relatively open mineral export and beneficiated product 


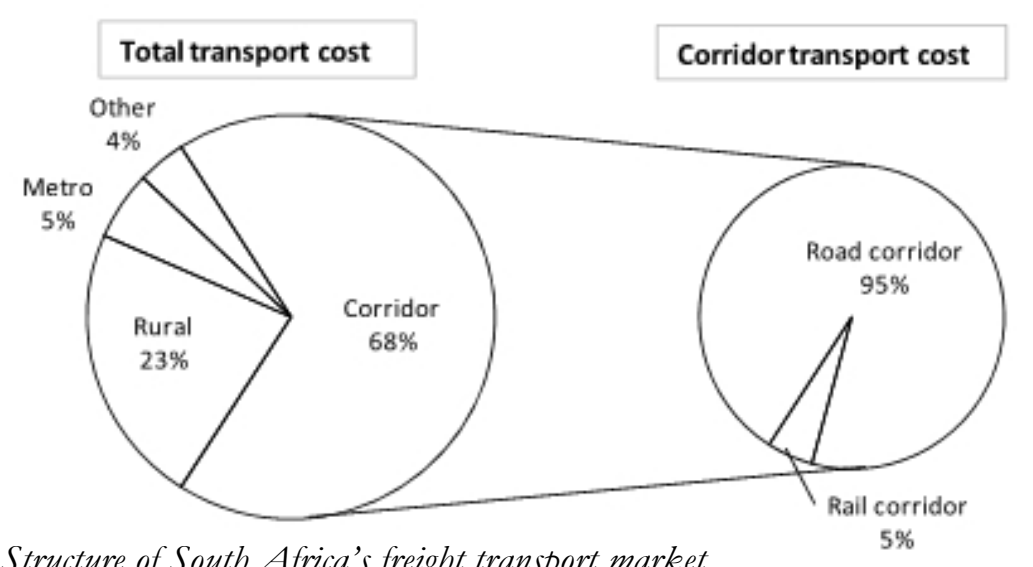

Figure 6. Structure of South Africa's freight transport market

$5 \%$

Notes: "Other" includes pipelines, coal on conveyer belts, and rail's ring-fenced coal and iron ore exports. "Rural" and "metro" include both rail and road transport.

and energy import economy, thereby creating long export and import corridor requirements (Havenga, 2007:4). However, the disproportionate transport demand is exacerbated by the fact that despite South Africa's long, dense transport corridors, the majority of corridor freight transport is by road. In terms of cost, $66 \%$ of total transport in 2008 was attributable to road transport on corridors, and $95 \%$ of corridor transport was by road ${ }^{11}$ (Fig. 6).

In addition, almost all growth over the already dense corridors occurred in the road transport mode, as depicted by the growth in road ton-kilometre market share in Fig. 7.12

This is especially disconcerting, given that the largest proportion of rail costs are of a fixed nature (Pietrantonio and Pelkmans, 2004:12) because of long-term infrastructural investment, while road transport costs are mostly variable and significantly exposed to volatile exogenous core cost drivers, for example the price of fuel. According to Hesse and Rodrigue (2004), the externality costs associated with road and air freight transport are also higher than those of rail and waterway freight transport modes.

The cost drivers of South Africa's road transport mode are illustrated in Fig. 8.

During 2008, South Africa's average diesel price increased by $49 \%$. Fuel contributes $30 \%$ of all road transport costs, while road transport's cost market share increased further

11 Cost market share on a typology basis is not available prior to 2008 , only ton-kilometre and ton market share. As mentioned previously, there are numerous challenges with granular freight transport market analysis in South Africa. The first cost model in 2003 supplied high-level information on South Africa's logistics cost and has been refined each subsequent year, culminating in the detailed 2008 model where granular cost market share comparisons can be made. The cost analysis will be done in future models, building on the 2008 results.

12 Ton-kilometre is the standard unit of measuring freight transport, as it considers both tons and distance travelled (Chasomeris, 2003:133). Dense corridors are ideal for rail or intermodal transport, as the density creates economies of scale because of the large volume of ton-kilometre generated. Intermodal transport magnifies these scale effects. According to Yevdokimov (2000:45), positive externalities arise because of scale effects that initiate cumulative economic growth. 


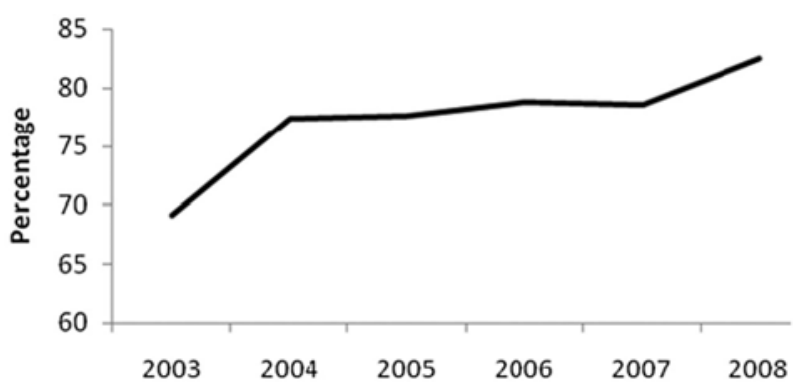

Figure 7. Road corridor (long distance) market share in South Africa (ton-kilometre)

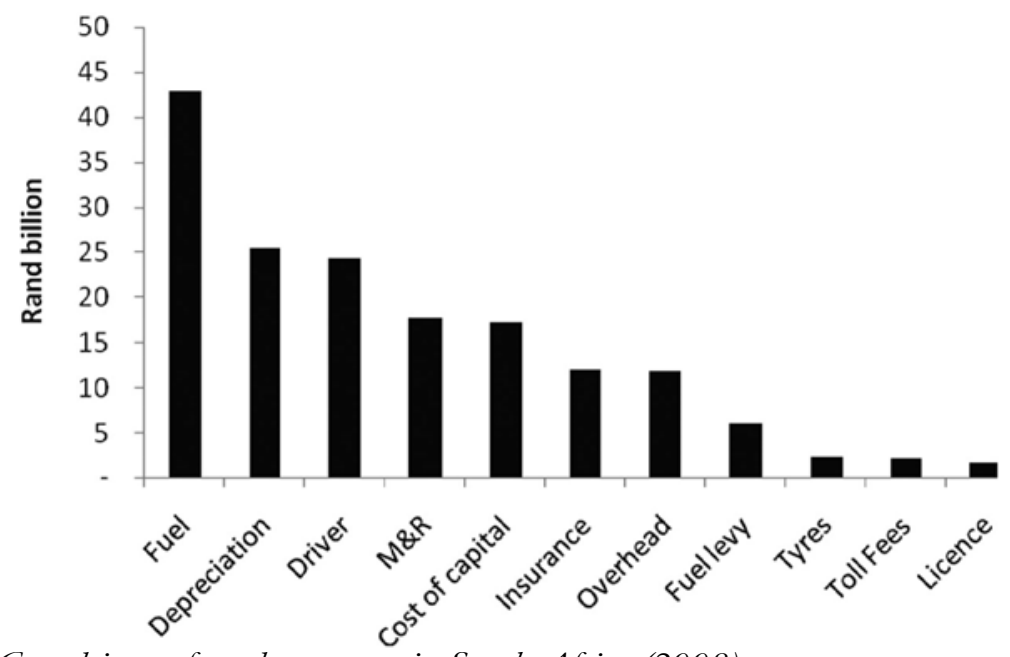

Figure 8. Cost drivers of road transport in South Africa (2008)

in 2008 to $91 \%$, increasing South Africa's already high vulnerability to fuel price fluctuations.

This means that $30 \%$ of transport and $14 \%$ of South Africa's logistics costs are exposed to direct external factors (given the current market share configuration as discussed above) and cannot be controlled by logisticians as such. Many other "hidden" aspects are also outside the sphere of control, such as the additional cost burden on operations caused by an ailing infrastructure. Furthermore, externalities that are not accounted for (such as congestion, accidents and pollution) add aspects that cannot be directly controlled at firm level.

In the short term, this exposure to externalities leads to ans inability to manage transport costs effectively, while over the longer term, it renders the economy vulnerable and less competitive globally.

The above analysis points to the second macroeconomic logistics indicator proposed for South Africa - road corridor market share in ton-kilometre terms. A downward trend in this indicator will mean progress towards a more sustainable structure in South Africa's transport market and a reduction in exposure to the exogenous fuel risk. 


\section{CONCLUSION AND POLICY RECOMMENDATION}

The macroeconomic imperative for tracking the key components of national logistics costs lies in the fact that a more efficient logistics system is one of the key pillars to create sustainable economic growth. Addressing the challenges in the national logistics system thus remains a key component of the government's national policy frameworks and continues to receive national strategic attention.

Without the ability to measure the current state of the national logistics system and the effect of policy and strategic interventions, it is impossible for government to address this challenge adequately. In fact, all macroeconomic decisions are driven by knowledge gained from indicators such as GDP growth, inflation and unemployment. It follows, therefore, that indicators providing feedback on the state of the logistics system and its performance should contribute to improved decision making in this area.

The development and annual application of the logistics cost model are key steps in addressing this absence of management information regarding South Africa's freight logistics efficiency, and as such, the model results confirm key areas requiring attention, namely:

- South Africa's logistics costs as a percentage of GDP are higher than those of industrialised countries, impacting on national competitiveness.

- The biggest cost contributor - road transport costs - can be executed more efficiently with intermodal solutions, which will also reduce the exposure to exogenous risk.

In turn, these areas translate into key macroeconomic logistics indicators that should inform government policy and enable the measurement of progress against policy implementation. Two initial indicators are proposed, namely:

- total logistics costs as a percentage of GDP (measures the overall performance of the system); and

- road corridor ton-kilometre market share (measures modal optimisation and resulting exposure to external risk).

It is proposed that as a starting point, these indicators should be included in the annual Development Indicators tracked under the section "Economic growth and transformation" by the presidency.

\section{REFERENCES}

ANDERSON, J. and VAN WINCOOP, E. (2004). Trade costs. Journal of Economic Literature, 42(3): 691-751.

ARVIS, J., MUSTRA, M. A., PANZER, J., OJALA, L. and NAULA, T. (2008). Connecting to compete: Trade logistics in the global economy. In R. Z. Lawrence, J. Blanke, M. D. Hanous and J. Moavenzadeh. The Global Enabling Trade Report. Geneva: The World Economic Forum.

BOGETI', Z. and FEDDERKE, J. (2006). International benchmarking of South Africa's infrastructure performance. Journal of Development Perspectives, 2(1): 7-31.

BOTES, F. J., JACOBS, C. G. and PIENAAR, W. J. (2006). A model to calculate the cost of logistics at a macro level: A case study of South Africa. Southern African Business Review, 10(3): 1-18.

BOWERSOX, D. J. and CLOSS, D. J. (1996). Logistical Management, the Integrated Supply Chain Process. New York: The McGraw-Hill Companies, Inc.

CHASOMERIS, M. G. (2003). South Africa's sea transport costs and port policy in a global context. Africana Bulletin, 51: 133-163. 
DEMKES, R. and TAVASSZY, L. A. (2000). Benchmarking Infrastructure and Logistics Services across Europe, Asia-Pacific and North America. Paper presented at the IMRL 2000 Third International Meeting for research in Logistics, Trois-Rivieres, 9-11 May 2000.

DEPARTMENT OF TRANSPORT. (2010). Discussion document from Cape Gauge to International Gauge. Available at: http://www.transport.gov.za/policy/railgaugedebate/part9.pdf [Accessed 30 September 2010].

EDWARDS, L. and LAWRENCE, R. (2006). South African Trade Policy Matters: Trade Performance \& Trade Policy. Centre for International Development at Harvard University, October 2006.

FEDDERKE, J., PERKINS, P. and LUIZ, J. (2006). Infrastructural investment in long-run economic growth: South Africa 1875-2001. World Development, 34(6): 1037-1059.

FOURIE, J. (2006). Economic infrastructure: A review of definitions, theory and empirics. South African Journal of Economics, 74(3): 530-556.

. (2008). A note on infrastructure quality in South Africa. Development Southern Africa, 25(4): 481-494.

FREDENDALL, L. D. and HILL, E. (2001). Basics of Supply Chain Management. Boca Raton, FL: The St. Lucie Press.

GORDHAN, P. (2010). Budget speech 2010. Available at: http://www.info.gov.za/speeches/2010/10021715051004.htm [Accessed 19 August 2010].

GOURDIN, K. N. (2001). Global Logistics Management: A Competitive Advantage for the New Millennium. Oxford: Blackwell Publishing Limited.

HANIVAL, S and MAIA, J. (2008). An overview of the performance of the South African economy since 1994. Input into the presidency's 15 year review process. Available at: http://www.thepresidency.gov.za/docs/reports/15year_review/ economic/economic_performance.pdf [Accessed 17 August 2010].

HAVENGA, J. H. (2007). The Development and Application of a Freight Transport Flow Model for South Africa. Unpublished Doctoral Thesis, University of Stellenbosch.

HESSE, M. and RODRIGUE, J. P. (2004). The transport geography of logistics and freight distribution. Journal of Transport Geography, 12(3): 171-184.

HOBBS, I. E. and HAVENGA, J. H. (2009). Logistics Facilitation and Trade Facilitation - A South African Case Study. Unpublished report for the World Bank at the Centre for Supply Chain Management, University of Stellenbosch.

LAKSHMANAN, T. R. and ANDERSON, W. P. (2002). Transportation Infrastructure, Freight Services and Economic Growth: A Synopsis of a White Paper. Washington, DC: The US Department of Transportation, Federal Highway Administration.

LIMÃO, N. and VENABLES, A. J. (2001). Infrastructure, geographical disadvantage, transport costs and trade. The World Banke Economic Review, 15(3): 451-479.

LOGISTICS NEWS. (2006). Supply chain foresight shows SA supply chain is a time bomb. March 2006: 2-3. -

. (2007). A new take on collaboration. June 2007: 2-3.

MACROSYS RESEARCH AND TECHNOLOGY. (2005). Logistics Costs and US Gross Domestic Product. Washington, DC: US Department of Transportation, Federal Highway Administration. Available at: http://ops.fhwa.dot.gov/freight/ freight_analysis/econ_methods/lcdp_rep/index.htm [Accessed 4 June 2010].

MITCHELL, M. (2006). Confronting land freight challenges in South Africa. Available at: http://www.sarf.org.za/news/ 18_Land_freight_issues.doc [Accessed 17 August 2010].

MOHR, P. and FOURIE, L. (1996). Ekonomie vir Suid-Afrikaanse studente. Pretoria: J.L. van Schaik Akademies.

NATIONAL TREASURY. (2009a). Provincial budgets and expenditure review: 2005/06-2011/12. Available at: http://www.treasury.gov.za/publications/igfr/2009/prov/default.aspx [Accessed 4 June 2010].

. (2009b). Estimates of public expenditure, 2009, transport. Available at: http://www.treasury.gov.za/documents/

Estimates $\% 20$ of $\% 20$ Public $\% 20$ Expenditure/2009/Vote $\% 2033$.pdf [Accessed 4 June 2010].

PERKINS, P., FEDDERKE, J. and LUIZ, J. (2005). An analysis of economic infrastructure investment in South Africa. South African Journal of Economics, 73(2): 211-228.

PIENAAR, W. J. (2005). Estimation of increased regional income that emanates from economically justified road construction projects. South African Journal for Science and Technology, 24(4): 108-117.

. (2008). Economic evaluation of the proposed road between Gobabis and Grootfontein, Namibia. South African Journal of Economics, 76(4): 667-684.

(2009). Introduction to business logistics. In W. J. Pienaar and J. J. Vogt (eds), Business Logistics Management. Cape Town: Oxford University Press, 1.

. (2010). The regulation of commercial petroleum pipeline operations: A South African example. Corporate Ownership \& Control, 7(3): 188-192.

PIETRANTONIO, L. D. and PELKMANS, J. (2004). The Economics of EU Railway Reform. Bruges European Economic Policy Briefings, College of Europe, Brugge.

RAVN, M. O. and MAZZENGA, E. (2004). International business cycles: The quantitative role of transportation costs. Journal of International Money and Finance, 23(4): 647-671.

RODRIGUES, A. M., BOWERSOX, D. J. and CALANTONE, R. J. (2005). Estimation of global and national logistics expenditures: 2002 data update. Journal of Business Logistics, 26(2): 1-16.

RODRIGUE, J-P, COMTOIS, C. and SLACK, B. (2009). The Geography of Transport Systems, 2nd edn. New York: Routledge.

ROSSOUW, C. (2006). Logistics News, October 2006: 13-15.

SAMUELSON, P. A. and NORDHAUS, W. D. (1989). Economics. New York: McGraw-Hill Book Company. 
THE PRESIDENCY. (1994). White paper on reconstruction and development. Government Gazette, 23 November. Available at: http://www.info.gov.za/view/DownloadFileAction?id=70427 [Accessed 30 September 2010] .

- (2007). Accelerated and shared growth initiative - South Africa (a summary). Available at: http://www.info. gov.za/asgisa/asgisadoc.pdf [Accessed 4 June 2010].

. (2009). Development indicators. Available at: http://www.info.gov.za/view/DownloadFileAction?id=109313 [Accessed 4 June 2010].

TRANSNET. (2009). Transnet national infrastructure plan, chapter 9: Five year capital plan. Available at: http://www.transnet.net/Documents/NIP\%20-\%20Chapter $\% 209 \% 20-\% 205 \% 20$ Year $\% 20$ Capital $\% 20$ Plan.pdf] [Accessed 4 June 2010].

UNITED NATIONS. (2002). Commercial Development of Regional Ports as Logistics Centres. New York: United Nations Publications.

US NATIONAL RESEARCH COUNCIL. (2002). Key Transportation Indicators: Summary of a Workshop. Committee on National Statistics. Washington, DC: National Academy Press, Division of Behavioural and Social Sciences and Education. WILSON, R. (2008). 19th Annual State of Logistics Report: Surviving the Slump. Washington, DC: Council for Supply Chain Management Professionals.

WORLD TRADE ORGANISATION. (2004). World trade report 2004: Coherence. Available at: http://www.wto.org/ english/res_e/publications_e/wtr04_e.htm [Accessed 4 June 2010].

YEVDOKIMOV, Y. V. (2000). Measuring economic benefits of intermodal transportation. Transport Law Journal, 27(3): 439-452.

\section{APPENDIX - INVENTORY CARRYING COSTS}

The increase in inventory carrying costs depicted in Figure 4 is discussed in more detail below.

Costs associated with storing inventory are largely influenced, on the one hand, by inventory volume and how long it is stored (managed by logisticians), and on the other hand, by interest rates and the cost of storage (largely 'administered costs', especially for interest rates, over which the logistician has little or no control). Table 1, below, reflects an analysis of the changes in storage costs.

Table 1. The causes of increased storage costs in 2008

\begin{tabular}{ll}
\hline Factor incurring change & $\mathbf{R}$ billion \\
Inflation & +3.7 \\
Increase in storage volume & -1.8 \\
Storage cost increase above & -4.3 \\
$\quad$ (decrease below) inflation & +3.6 \\
Delay in inventory & +1.2 \\
\hline
\end{tabular}

The R1.2 billion net increase in storage costs is a result of storing slightly less inventory at slightly lower real storage rates for a longer period of time - a mixed result for efficiency and a positive result as far as price increases (price negotiating ability) are concerned.

Unfortunately, the positive effect of lower storage rates is negated by higher inventory carrying costs. The trend with inventory carrying costs, which once again were much higher in $2008(21.2 \%$ higher than in 2007), is illustrated in Figure 4. The reasons for the increase in costs are twofold; firstly, the average weighted interest rate increased from $13 \%$ to $15 \%$ between 2007 and 2008, and secondly, the levels of inventory increased. The change in interest rates contributed $40 \%$ to the increase in inventory carrying costs, while the increase in inventory levels contributed the remaining $60 \%$ of the increase. 